\title{
Hubungan Tingkat Pengetahuan Masyarakat tentang COVID-19 dengan Kesadaran Masyarakat dalam Menggunakan Masker
}

\author{
The Relationship of Community Knowledge Levels on Covid-19 with \\ Community Awareness in Mask Usage
}

\author{
Sipa Maulani*, Supriyadi² \\ 1. STIKes Surya Global Yogyakarta, Indonesia \\ 2. STIKes Surya Global Yogyakarta, Indonesia \\ *Email Korespondensi: sipamaulani05@gmail.com
}

\begin{abstract}
Abstrak
Latar Belakang: Dunia saat ini tengah waspada dengan penyebaran virus corona (COVID-19). Tingkat mortalitas COVID-19 di Indonesia sebesar 8,9\%, angka ini merupakan yang tertinggi di Asia Tenggara. WHO merekomendasikan penggunaan masker sebagai salah satu pencegahan COVID-19. Penggunaan masker diperlukan bagi setiap orang agar tidak saling menulari virus corona. Namun, sebagian besar masyarakat masih belum sepenuhnya memahami tentang COVID-19. Hal tersebut dapat mempengaruhi dari kesadaran masyarakat dalam meggunakan masker.

Tujuan: Penelitian ini bertujuan untuk mengetahui apakah ada hubungan tingkat pengetahuan masyarakat tentang COVID-19 dengan kesadaran masyarakat dalam menggunakan masker.

Metode: Jenis penelitian kuantitatif dengan menggunakan pendekatan cross sectional. Sampel penelitian ini sebanyak 54 responden. Pemilihan sampel menggunakan consecutive sampling. Data diambil menggunaan kuesioner dan dianalisis menggunakan Kendall-Tau.

Hasil: Hasil penelitian menunjukkan tingkat pengetahuan masyarakat mayoritas baik sebanyak 37 orang $(68,5 \%)$ dan mayoritas kesadaran masyarakat tinggi dalam penggunaan masker sebanyak 34 orang $(63,0 \%)$. Hasil uji korelasi menunjukkan ada hubungan yang signifikan antara tingkat pengetahuan tentang COVID-19 dengan kesadaran dalam menggunakan masker dengan nilai signifikan $p$ value 0,000 $(<0,01)$ dengan koefisien korelasi 0,809.
\end{abstract}

Kesimpulan: Ada hubungan antara tingkat pengetahuan masyarakat tentang COVID-19 dengan kesadaran masyarakat dalam menggunakan masker.

Kata Kunci: COVID-19; Kesadaran; Masker; Tingkat Pengetahuan

\begin{abstract}
Background: The world is currently facing the spread corona virus (COVID-19). The mortality rate for COVID-19 in Indonesia is 8.9\%, this figure is the highest in Southeast Asia. WHO recommends the use of masks as one of the prevention of COVID-19. Using mask is compulsory for everyone to stop the spread of corona virus. However, the understanding is still low and it affects the awareness in mask usage.
\end{abstract}

Objective: This study aimed to determine the relationship between public knowledge about COVID-19 and public awareness of using masks.

Methods: This was a cross sectional quantitative study. The sample of this research consisted of 54 respondents. Consecutive sampling was used, the data were collected using a questionnaire and analyzed using Kendall tau.

Results: The results showed that majority of community with good knowledge were 37 people (68.5\%) and community with high awareness were 34 people (63.0\%). The results of the correlation test showed a significant relationship between the level of knowledge about COVID-19 and awareness of using masks with $p$ value of $0.000(<0.01)$, and coefficient correlation of 0.809 .

Conclusion: There was a relationship between public knowledge about COVID-19 and public awareness of using masks.

Keywords: Awareness; COVID-19; Knowledge Level; Mask 


\section{PENDAHULUAN}

Dunia saat ini tengah waspada dengan penyebaran virus corona. Coronaviruses $(\mathrm{CoV})$ merupakan bagian dari keluarga virus yang menyebabkan penyakit mulai dari flu hingga penyakit yang lebih berat seperti Middle East Respiratory Syndrome (MERS-CoV) and Severe Acute Respiratory Syndrome (SARS-CoV). Penyakit yang disebabkan virus corona, atau dikenal dengan COVID-19 adalah jenis baru yang ditemukan pada tahun 2019 dan belum pernah diidentifikasi menyerang manusia sebelumnya(1).

Kasus virus corona muncul dan menyerang manusia pertama kali di provinsi Wuhan, China. Awal kemunculannya diduga merupakan penyakit pneumonia, dengan gejala serupa sakit flu pada umumnya. Gejala tersebut di antaranya batuk, demam, letih, sesak napas, dan tidak nafsu makan. Namun, berbeda dengan influenza, virus corona dapat berkembang dengan cepat hingga mengakibatkan infeksi lebih parah dan gagal organ. Terhitung pada tanggal 6 Juni 2020 pukul 13:32 kasus COVID-19 di seluruh dunia sudah mencapai 6.724.516 orang positif dan 394.018 orang meninggal dunia. Kasus tertinggi COVID-19 di dunia terdapat di Negara Amerika Serikat dengan jumlah kasus 1.936 .967 orang positif dan 110.708 orang meninggal $\operatorname{dunia}(2)$.

Pada tanggal 30 Maret 2020, terdapat 693.224 kasus dan 33.106 kematian di seluruh dunia. Eropa dan Amerika Utara telah menjadi pusat pandemi COVID-19, dengan kasus dan kematian sudah melampaui China(3). Amerika Serikat menduduki peringkat pertama dengan kasus COVID-19 terbanyak dengan penambahan kasus baru sebanyak 19.332 kasus pada tanggal 30 Maret 2020 disusul oleh Spanyol dengan 6.549 kasus baru. Italia memiliki tingkat mortalitas paling tinggi di dunia, yaitu 11,3\%(3).

COVID-19 pertama dilaporkan di Indonesia pada tanggal 2 Maret 2020 sejumlah dua kasus. Data 31 Maret 2020 menunjukkan kasus yang terkonfirmasi berjumlah 1.528 kasus dan 136 kasus kematian.Tingkat mortalitas COVID-19 di Indonesia sebesar 8,9\%, angka ini merupakan yang tertinggi di Asia Tenggara(1). Kasus di Indonesia sendiri menepati urutan ke 34 se-dunia dengan jumlah kasus 29.521 orang positif, 1.770 orang meninggal dunia dan 9.443 orang dinyatakan sembuh. Jawa Barat adalah salah satu provinsi yang berada di zona merah kasus COVID-19. Jawa Barat berada di urutan ke 3 se-Indonesia setelah Jakarta dan Jawa Tengah, dengan jumlah kasus di Jawa Barat sebanyak 2.366 orang positif, 764 orang dinyatakan sembuh dan 158 orang meninggal dunia. Kabupaten Garut adalah salah satu yang memberlakukan PSBB (Pembatasan Sosial Bersekala Besar) di provinsi Jawa Barat, dengan kasus mengalami kenaikan(4).

COVID-19 merupakan penyakit menular yang berpotensi menimbulkan kedaruratan kesehatan masyarakat, di Indonesia pemerintah telah memberikan himbauan-himbauan kepada masyarakat dalam mengatasi wabah ini. Pemerintah juga membuat berbagai peraturan terkait dengan pencegahan COVID-19 ini wajib dibentuk dalam Peraturan Pemerintah dan Peraturan Menteri Kesehatan karena kedua peraturan tersebut merupakan peraturan pelaksanaan daripada Undang-Undang Nomor 6 Tahun 2018 tentang Kekarantinaan Kesehatan(5). Berdasarkan analisis penulis, ada 5 Peraturan Pemerintah yang wajib dibentuk dalam rangka melakukan tindakan penanggulangan dan pencegahan ancaman penyakit yang mudah menular seperti COVID-19 dan ada 11 Peraturan Menteri Kesehatan terkait yang wajib dibentuk dalam rangka mengantisipasi ancaman COVID-19. Oleh karena itu penelitian mengambil dua jenis peraturan tersebut sangat berguna dalam hal mengantisipasi kedaruratan kesehatan yang pada akhirnya menjurus pada kekarantinaan kesehatan masyarakat Indonesia. Kiranya kedua jenis peraturan ini segera dibuat dalam rangka memberi kepastian hukum dalam mencegah menularnya COVID-19 secara meluas(5).

Salah satu cara dari Pedoman Pencegahan dan Pengendalian virus yaitu menggunakan masker. Masker ini dibedakan menjadi beberapa jenis, yaitu masker medis untuk petugas medis 
yang sedang melaksanakan kewajiban serta pasien yang sedang sakit, untuk masyarakat diharapkan menggunakan masker kain. Penggunaan masker dimaksudkan untuk mencegah terjadinya penularan virus covid-19 melalui media droplet. Pada Surat Edaran Nomor HK.02.01/MENKES/216/2020 tentang Protokol Pencegahan Penularan Coronavirus Disease (Covid-19) di tempat kerja juga menginformasikan dan mengedukasi kepada masyarakat untuk melaksanakan Perilaku Hidup Bersih dan Sehat (PHBS), salah satunya adalah menggunakan masker di Jawa Barat(6).

Badan Kesehatan Dunia mengubah kebijakan dan kini mendukung penggunaan masker untuk semua orang di tengah penyebaran pandemi Covid-19 akibat infeksi virus corona (SARSCoV-2). Sebelumnya, WHO merekomendasikan penggunaan masker hanya untuk orang sakit dan orang yang merawat pasien. WHO menyatakan masker bedah harus disediakan untuk petugas medis, sementara masyarakat bisa menggunakan masker berbahan kain untuk menutup wajah(3).

Studi terbaru oleh Komisi Tetap Penyakit Menular dan Ancaman Abad 21 di Amerika Serikat menyebut virus corona bisa menular melalui percakapan dan pernapasan normal dengan orang yang terpapar. Kesimpulan studi yang dipublikasikan di laman Academy of Science Engineering Medicine dan menjawab pertanyaan resmi Gedung Putih, secara tegas menyebut bahwa virus corona bisa menyebar hanya melalui percakapan dan pernapasan. Penggunaan masker diharuskan juga terkait dengan percikan liur atau droplet. Penelitian terbaru menunjukkan batuk dan bersin dapat membuat percikan liur terlontar lebih jauh daripada yang diperkirakan sebelumnya. Surat Edaran Nomor HK.02.01/MENKES/216/2020 tentang Protokol Pencegahan Penularan Coronavirus Disease telah diberlakukan untuk mencegah penularan COVID-19(6).

Namun, sebagian besar masyarakat masih belum sepenuhnya memahami pentingnya menggunakan masker ketika harus keluar rumah secara langsung dengan orang lain. Hal tersebut ditandai dari hasil studi pendahuluan yang dilakukan oleh peneliti kepada salah satu kapolsek yang bertugas di jalan raya mengatakan masih banyak masyarakat yang kurang memiliki kesadaran untuk menggunakan masker ketika harus keluar rumah, padahal penyakit ini dapat menyebar melalui tetesan kecil dari hidung atau mulut pada saat batuk atau bersin, dan hasil studi pendahuluan kepada 5 orang masyarakat sekitar diketahui ada 2 responden mengetahui pengertian, cara penyebaran serta pencegahan COVID-19 dan 3 orang masyarakat sekitar mengetahui pengertian COVID-19 tetapi masih belum mengetahui pencegahan COVID19 tertama dan penggunaan masker. Beberapa masyarakat sekitar mengatakan bahwa penggunaan masker sangat penting, namun ada sebagian masyarakat juga mengatakan menggunakan masker membuat dirinya tidak bisa bernafas dengan lega atau terasa pengap(7).

\section{METODE}

Penelitian ini merupakan jenis penelitian kuantitatif dengan menggunakan pendekatan cross sectional. Penelitian ini dilaksanakan di Kampung Sindang Sari RT 001 RW 006 Desa Ciburial Kabupaten Garut Jawa Barat, dilakukan pada bulan September 2020. Populasi dalam penelitian ini terdiri dari 118 orang, penentuan sampel yang akan diambil peneliti menggunakan rumus Slovin dengan hasil jumlah sampel sebanyak 54 orang. Responden yang berpartisipasi dalam penelitian ini adalah masyarakat dengan kriteria inklusi yaitu masyarakat yang berdomisili di Kampung Sindang Sari RT 001 RW 006 dan berusia $\geq 15-45$ tahun. Sedangkan kriteria eksklusi dalam penelitian ini yaitu masyarakat yang mengalami sakit flu, batuk atau demam. Teknik sampel dalam penelitian ini menggunakan consecutive sampling, dimana semua subjek yang datang dan memenuhi kriteria pemilihan dimasukkan penelitian sampai jumlah subjek yang diperlukan terpenuhi. Penelitian ini dilakukan dengan mendatangi setiap masyarakat yang telah memenuhi kriteria untuk mengisi kuesioner tingkat pengetahuan tentang COVID-19 Dengan 
hasil uji validitas $r$ hitung 0,372-0,639 dan uji reliabilitas dihitung menggunakan rumus Alpha Cronbach dengan SPPS 16 for Windows diperoleh nilai sebesar 0,813, kuesioner kesadaran dalam menggunakan masker dengan hasil uji validitas dengan $r$ hitung 0,417-0,814 dan uji reliabilitas diperoleh nila sebesar 0,828 , penelitian ini dilakukan sesuai dengan protokol kesehatan. Analisis data menggunakan analisis univariat dengan mencari distribusi frekuensi dan analisis bivariat yang digunakan analisis statistik kolerasi Kendall-Tau. Hipotesis dalam penelitian ini yaitu Ha: ada hubungan tingkat pengetahuan masyarakat tentang COVID-19 dengan kesadaran masyarakat dalam menggunakan masker. Ho: tidak ada hubungan tingkat pengetahuan masyarakat tentang COVID-19 dengan kesadaran masyarakat dalam menggunakan masker. Penelitian dinyatakan layak etik dari Komite Etik Penelitian Kesehatan STIKES Surya Global Yogyakarta dengan nomor 2.19/KEPK/SSG/IX/2020. Semua responden penelitian telah memberikan informed consent

\section{HASIL}

Penelitian ini memfokuskan pada mempelajari tingkat pengetahuan masyarakat tentang kejadian pandemi COVID-19 dan kesadaran dalam menggunakan masker.

Tabel 1. Distribusi Frekuensi Karakteristik Reponden Masyarakat di Kampung Sindang Sari Garut Jawa Barat $(n=54)$

\begin{tabular}{lcc}
\hline Karakteristik & Frekuensi & Persentase (\%) \\
\hline 1. Umur & 19 & $35,2 \%$ \\
a. $15-25$ & 21 & $38,9 \%$ \\
b. $26-35$ & 14 & $25,9 \%$ \\
c. $36-45$ & & \\
\hline 2. Jenis Kelamin & 29 & $53,7 \%$ \\
a. Perempuan & 25 & $46,3 \%$ \\
b. Laki-laki & & \\
\hline 3. Pendidikan & 10 & $18,5 \%$ \\
a. SD & 20 & $37,0 \%$ \\
b. SMP/SLTP/MTS & 19 & $35,2 \%$ \\
c. SMA/SLTA/SMK & 5 & $9,3 \%$ \\
d. Perguruan Tinggi (PT) & & \\
\hline 4. Pekerjaan & 14 & $25,9 \%$ \\
a. Ibu Rumah Tangga (IRT) & 24 & $44,4 \%$ \\
b. Karyawan/Wiraswasta & 4 & $7,4 \%$ \\
c. Petani/Buruh & 5 & $9,3 \%$ \\
d. PNS/TNI/Guru/Perawat & 7 & $13,0 \%$ \\
e. Pelajar/Mahasiswa & & \\
\hline
\end{tabular}

Berdasarkan tabel 1 karakteristik umur masyarakat, menunjukkan bahwa mayoritas responden pada penelitian ini dengan rentang umur 26-35 tahun yang berjumlah 21 responden. Hasil analisis berdasarkan tabel, distribusi jenis kelamin responden dalam penelitian ini menunjukkan bahwa mayoritas berjenis kelamin perempuan, yaitu sebanyak 29 orang. Dilihat dari karakteristik pendidikan terakhir menunjukkan bahwa mayoritas pendidikan terakhirnya adalah berpendidikan SMP yaitu sebanyak 20 responden. Dilihat dari karakteristik pekerjaan mayoritas responden Karyawan/Wiraswasta sebanyak 24 responden. Menurut peneliti bahwa yang mempengaruhi pekerjaan responden adalah lingkungan tempat tinggal responden, karena lingkungan tempat tinggal responden dekat dengan kawasan pabrik-pabrik besar. 
Tabel 2. Distribusi Tingkat Pengetahuan Masyarakat di Kampung Sindang Sari Garut Jawa Barat

\begin{tabular}{ccc}
\hline Tingkat Pengetahuan & Frekuensi & Persentase (\%) \\
\hline Baik & 37 & $68,5 \%$ \\
Cukup & 14 & $25,9 \%$ \\
Kurang & 3 & $5,6 \%$ \\
\hline Total & $\mathbf{5 4}$ & $\mathbf{1 0 0} \%$ \\
\hline
\end{tabular}

Berdasarkan tabel 2 tingkat pengetahuan masyarakat tentang COVID-19 di Kampung Sindang Sari RT 001 RW 006 Kabupaten Garut Jawa Barat dengan mayoritas baik $(68,5 \%)$.

Tabel 3. Distribusi Kesadaran Menggunakan Masker di Kampung Sindang Sari Garut Jawa Barat

\begin{tabular}{ccc}
\hline Kesadaran & Frekuensi & Persentase (\%) \\
\hline Tinggi & 34 & $63,0 \%$ \\
Sedang & 18 & $33,3 \%$ \\
Rendah & 2 & $3,7 \%$ \\
\hline Total & $\mathbf{5 4}$ & $\mathbf{1 0 0} \%$ \\
\hline
\end{tabular}

Dilihat dari tabel 3 bahwa mayoritas kesadaran responden dalam menggunakan masker tinggi $(63,0 \%)$.

Tabel 4. Hasil Uji Korelasi Kendall-Tau Hubungan Tingkat Pengetahuan Dengan Kesadaran Menggunakan Masker Di Kampung Sindang Sari Garut Jawa Barat

\begin{tabular}{ccc}
\hline Variabel & Nilai koefisiensi Korelasi & p-value \\
\hline Tingkat Pengetahuan & 0.809 & 0,000 \\
\hline Kesadaran & & 0 \\
\hline
\end{tabular}

Berdasarkan tabel 4 nilai korelasi Kendall-Tau antara tingkat pengetahuan tentang COVID-19 dengan kesadaran menggunakan masker menunjukkan $p$ value $0,000(<0,01)$. Hal ini menunjukkan bahwa terdapat hubungan antara tingkat pengetahuan tentang COVID-19 dengan kesadaran menggunakan masker pada masyarakat di Kampung Sindang Sari RT 001 RW 006 Desa Ciburial Kecamatan Leles Garut.

\section{PEMBAHASAN}

Berdasarkan hasil uji yang telah dilakukan sebagian masyarakat di Kampung Sindang Sari RT 001 RW 006 Garut Jawa Barat dengan jumlah responden sebanyak 54 orang, menunjukkan bahwa tingkat pengetahuan masyarakat tentang COVID-19 mayoritas responden dengan tingkat pengetahuan baik sebanyak 37 orang $(68,5 \%)$. Hal ini dikarenakan mayoritas sampel pada penelitian ini memiliki usia 26 sampai 35 tahun, berjenis kelamin perempuan, dan mayoritas semua sampel bekerja, selain itu tingkat pengetahuan yang tinggi ini juga didukung dengan tingkat pendidikan. Tingkat pendidikan seseorang tinggi akan semakin mudah seseorang untuk mendapatkan akses informasi tentang suatu permasalahan dan memiliki informasi serta daya ingat yang cukup sehingga mempengaruhi tingkat pengetahun masyarakat tentang COVID-19. Penelitian ini sejalan dengan penelitian yang dilakukan oleh Nugroho Utomo (2015) yang menunjukkan bahwa tingkat pengetahuan pekerja tentang resiko penyakit dengan kesadaran menggunakan masker ditempat kerja dengan hasil sangat baik sebanyak 22 orang $(53,7 \%)(8)$. Pengetahuan masyarakat tentang COVID-19 merupakan aspek yang sangat 
penting dalam masa pandemic seperti sekarang ini yang meliputi penyebab COVID-19 dan karakteristik virusnya, tanda dan gejala, istilah yang terkait dengan COVID-19, pemeriksaan yang diperlukan dan proses transmisi serta upaya pencegahan penyakit tersebut(9). Penelitian yang dilakukan oleh Yanti B, dkk (2020) yang menunjukkan bahwa 99\% masyarakat Indonesia mempunyai tingkat pengetahuan yag baik(10). Hasil penelitian berdasarkan karakteristik pendidikan terakhir yang mana responden dalam penelitian ini riwayat pendidikan terkahir mayoritas SMP/SLTP/MTS sebanyak 20 orang (37,0\%). Dimana pengetahuan dapat dipengaruhi oleh pendidikan seseorang.

Hasil penelitian menunjukkan bahwa terdapat hubungan yang signifikan antara tingkat pengetahuan tentang COVID-19 dengan kesadaran dalam menggunakan masker yang diperoleh dari nilai signifikan $p$ value $=0,000<0,01$, maka Ho ditolak dan Ha diterima. Sama halnya dengan penelitian Nugroho Utomo (2015) yang menunjukkan bahwa semakin tinggi tingkat pengetahuan pekerja tentang resiko penyakit akibat kerja, maka akan semakin tinggi tingkat kesadaran pekerja untuk memakai masker ketika bekerja(8).

Salah satu faktor internal yang mempengaruhi tingkat pengetahuan seseorang adalah pendidikan, semakin tinggi tingkat pendidikan seseorang maka semakin tinggi pula pengetahuannya(11). Penelitian lain yang sejalan dengan hasil penelitian ini adalah penelitian yang dilakukan oleh Clements JM (2020), yang menunjukan bahwa masyarakat Amerika Serikat memiliki pengetahuan dan perilaku yang baik(12). Selain faktor tingkat pendidikan, jenis kelamin merupakan salah satu faktor yang mempengaruhi tingkat pengetahuan. Dalam hasil penelitian berdasakan karakteristik jenis kelamin mayoritas perempuan sebanyak 29 orang (53,7 \%). Sebuah penelitian di Arab Saudi menunjukkan bahwa perempuan memiliki tingkat pengetahuan yang baik tentang COVID-19(13).

Hasil penelitian berdasarkan karekteristik pekerjaan masyarakat mayoritas karyawan/wiraswasta sebanyak 24 orang $(44,4 \%)$. Masyarakat di Kampung Sindang Sari mayoritas karyawan/wiraswasta karena lokasi kampong berdeketan dengan salah satu pabrik.

Menurut Notoadmojo (2018) pengetahuan juga dipengaruhi oleh faktor pekerjaan dimana seseorang yang bekerja disektor formal memiliki akses yang lebih baik terhadap informasi termasuk informasi kesehatan, faktor sosial, budaya dan ekonomi dimana kebiasaan dan tradisi seseorang tidak melalui suatu penalaran tetapi bersifat rutinitas. Pada penelitian ini hasil karakteristik berdasarkan umur masyarakat adalah mereka yang masih dalam usia produktif yaitu 26-35 tahun, di mana usia produktif memiliki daya tangkap yang lebih besar.

Faktor usia mempengaruhi daya tangkap dan pola pikir seseorang, semakin bertambah usia maka akan semakin berkembang pula daya tangkap dan pola pikirnya sehingga pengetahuan yang diperoleh semakin baik. Usia rata-rata responden yang mengisi kuisioner ini berusia 20 tahun, dengan usia responden termuda yaitu 17 tahun dan yang paling tua berusia 45 tahun (Notoadmojo, 2018). Hal ini sesuai dengan penelitian yang dilakukan oleh Pangesti (2012), bahwa pada usia produktif merupakan usia yang paling berperan dan memiliki aktivitas yang padat serta memiliki kemampuan kognitif yang baik. Sehingga, pada usia ini memiliki pengaruh terhadap tingkat pengetahuan(14).

Faktor lain juga turut mempengaruhi tingkat pengetahuan tentang COVID-19 adalah sumber informasi. Kemajuan dibidang teknologi membuat seluruh lapisan masyarakat semakin mudah mengakses informasi terkait COVID-19. Penelitian tentang sumber informasi COVID19 pada mahasiswa di Jordania menunjukkan bahwa mayoritas mahasiswa menggunakan internet, media sosial, dan media massa sebagai sumber informasi tentang COVID-19(15).

Saat ini perkembangan teknologi informasi semakin besar, akses internet juga semakin tinggi. Sejak diketahuinya kasus pertama COVID-19 di Indonesia, seluruh media massa memberikan pesan-pesan kesehatan agar terhindar dari keterpaparan terhadap COVID-19. 
Internet sebagai salah satu media massa yang banyak digunakan oleh masyarakat dapat memberikan informasi terkait COVID-19.

Pada tabel 6 tentang menunjukkan bahwa tingkat kesadaran masyarakat dalam menggunakan masker dalam kategori tinggi 34 (64,8\%), kategori sedang 18 (33,3\%), dan kategori rendah $2(3,7 \%)$. Hal ini menunujukkan bahwa mayoritas kesadaran masyarakat dalam menggunakan masker di Kampung Sindang Sari RT 01 RW 06 Garut memiliki kesadaran tinggi. Kesadaran masyarakat, menjadi kunci utama dalam upaya memutus rantai penyebaran penyakit menular mematikan itu. Apapun konsep yang dilakukan, entah itu lockdown atau social, jika masyarakat tidak bisa disiplin dan punya kesadaran tinggi, itu tidak akan pernah berhasil(16). Berdasarkan data karakteristik responden, menunjukkan bahwa mayoritas usia berkisar 26-35 tahun sebanyak 21 orang (38,9 \%). Bertambahnya umur seseorang maka akan mempunyai banyak pengalaman dan akan memiliki kecerdasan dalam berpikir.

Menurut Notoatmodjo (2012), perilaku merupakan perpaduan antara faktor internal yang terdiri dari kecerdasan, persepsi, motivasi, minat dan emosi dan faktor eksternal yang terdiri dari obyek kelompok dan hasil kebudayaan. Perilaku juga bergantung pada karakteristik atau faktor lain dari tenaga kerja itu sendiri. Salah satu karakteristik dari tenaga kerja adalah faktor umur yang mempengaruhi perilaku untuk secara sadar menggunakan APD (masker).

Berdasarkan data karakteristik pendidikan, menunjukkan bahwa mayoritas pendidikan terakhir responden SMP/SLTP/MTS sebanyak 20 orang (37,0 \%). Kesadaran masyarakat untuk memakai masker pada saat keluar rumah tinggi, karena responden memiliki tingkat pendidikan yang cukup tinggi, yaitu berpendidikan SMP/SLTP/MTS sehingga respoden memiliki pengetahuan yang cukup tentang COVID-19. Sejalan dengan penelitian yang dilakukan oleh Nugroho Utomo (2015), bahwa pendidikan merupakan faktor yang memiliki hubungan dengan kesadaran menggunakan APD(8).

Hal ini diperkuat oleh penelitian yang pernah dilakukan oleh Zone Nur Hiday (2013) dengan judul "faktor-faktor yang berhubungan dengan praktik penggunaan masker pada pekerja bagian pencelupan benang di PT X Kabupaten Pekalongan" kepada 49 responden yang diambil secara total sampling. Dilihat dari aspek pendidikan dalam penelitian ini dengan menggunakan uji statistik didapatkan terdapat hubungan antara pendidikan dengan praktik penggunaan masker pada pekerja dibagian pencelupan benang dengan $p$ value 0,014 . Dari penjelasan di atas dapat penulis asumsikan bahwa pendidikan seseorang akan mempengaruhi tingkat pengetahuannya, yang mana bila dikaitkan dengan kesadaran penggunaan masker oleh petugas pada saat bekerja sangat dipengaruhi oleh pengetahuan petugas akan manfaat dari masker serta kerugian jika tidak menggunakannya. Hal itu dikarenakan semakin tinggi tingkat pendidikan seseorang maka semakin baik pula pengetahuan yang dimilikinya yang kemudian akan semakin baik pula perilaku yang diperlihatkannya(17).

Adhityo Soendoro (2016) menunjukkan bahwa ada hubungan yang signifikan antara pengetahuan dengan pemakaian APD dengan nilai p-value $0,000<0,05(18)$. Penelitian ini sejalan dengan Aziz (2014) hasil analisis hubungan tingkat pengetahuan keselamatan dan kesehatan kerja terhadap kedisiplinan pemakaian masker dengan menggunakan uji statistik korelasi product momen didapatkan nilai signifikasi (p) sebesar 0,001, dengan demikian Ho ditolak dan $\mathrm{Ha}$ diterima, maka terdapat hubungan antara tingkat pengetahuan dengan kedisiplinan pemakaian masker pada pekerja bagian Winding PT. Iskandar Indah Printing Textile Surakarta (Aziz, 2014).

Pada penelitian Christina Yuliastuti dkk (2014) terdapat hubungan antara tingkat pengetahuan tentang TB Paru dengan penggunaan masker di Ruang Paru Rumkital Dr. Ramelan Surabaya. Hal ini menunjukkan bahwa tingkat pengetahuan yang kurang pada responden mendorong responden berperilaku negatif terhadap upaya pencegahan penyakit dengan tidak 
menggunakan masker saat menjaga atau mengunjungi pasien TB Paru di Ruang Paru Rumkital Dr. Ramelan Surabaya(19).

Hal ini juga sejalan dengan penelitian yang dilakukan oleh Sari (2020) dimana tingkat pengetahuan masyarakat mempengaruhi kepatuhan menggunakan masker sebagai upaya pencegahan penyebaran virus corona(20). Berdasarkan hasil analisis hubungan tingkat pengetahuan tentang COVID-19 dengan kesadaran menggunakan masker dapat diketahui bahwa tingkat pengetahuan responden berhubungan dengan kesadaran dalam menggunakan APD (masker), apabila tingkat pengetahuannya baik maka responden memliki tingkat kesadaran dalam menggunakan masker tinggi, namun sebaliknya apabila pengetahuan kurang maka responden juga memiliki tingkat kesadaran dalam menggunakan masker rendah.

\section{SIMPULAN}

Berdasarkan hasil penelitian dan analisis maka dapat disimpulkan bahwa, tingkat pengetahuan masyarakat tentang COVID-19 di Kampung Sindang Sari RT 001 RW 006 Desa Ciburial Kecamatan Leles Garut dalam kategori baik yaitu sebanyak 37 responden (68,5 \%). Kesadaran masyarakat dalam menggunakan masker di Kampung Sindang Sari RT 001 RW 006 Desa Ciburial Kecamatan Leles Garut dalam kategori tinggi yaitu sebanyak 34 orang (63,0 \%). Ada hubungan antara tingkat pengetahuan masyarakat tentang COVID-19 dengan kesadaran masyarakat dalam menggunakan masker di Kampung Sindang Sari RT 001 RW 006 Desa Ciburial Kecamatan Leles Garut dengan nilai $p$ value sebesar 0,000 ( $p$ value <0,01).

\section{SARAN}

Adapun saran berdasarkan hasil penelitian adalah memberikan informasi terkait cara penyebaran COVID-19, baik pencegahannya salah satunya dengan menggunakan masker sehingga dapat mengurangi jumlah orang yang mengalami COVID-19. Selain itu, sebagai bahan referensi dan tambahan informasi tentang komponen yang berperan dalam proses pemakaian masker yaitu dengan adanya edukasi dari pihak-pihak yang terkait. Menambah referensi wilayah atau daerah target pengabdian masyarakat di bidang kesehatan dalam pencegahan terjadinya peningkatan jumlah COVID-19 berbasis masyarakat terkait penggunaan masker dengan melibatkan semua komponen meliputi masyarakat, tenaga medis dan pemerintah. Kemudian, melakukan penelitian lanjutan dengan variabel lain yang belum diteliti untuk mengetahui lebih luas terkait faktor apa saja yang berpengaruh terhadap tingkat pengetahuan masyarakat dalam menggunakan masker upaya pencegahan COVID-19.

\section{UCAPAN TERIMA KASIH}

Ucapan terima kasih disampaikankhususnya kepada Pak Supriyadi Selaku dosen pembimbing dan kepada masyarakat kampung Sindang Sari Garut Jawa Barat atas partisipasi, kerja sama, perizinananya dan umumnya kepada semua pihak yang telah terlibat dalam penelitian ini.

\section{DAFTAR PUSTAKA}

1. World Health Organization. Naming the coronavirus disease (COVID-19) and the virus that causes it [Internet]. World Health Organization. 2020. p. 1. Available from: https://www.who.int/emergencies/diseases/novel-coronavirus-2019/technicalguidance/naming-the-coronavirus-disease-(covid-2019)-and-the-virus-that-causes-it

2. CSSE. 14-CSSE COVID - 19 [Internet]. Johns Hopkins University; 2020. Available from: https://en.wikipedia.org/wiki/Template:COVID-19_pandemic_data\#cite_noteJHU_ticker-6 
3. World Health Organization. 65-Coronavirus Disease (COVID-19) Situation Reports [Internet]. World Health Organization; 2019. Available from: https://www.who.int/emergencies/diseases/novelcoronavirus2019/technicalguidance/naming-the-coronavirusdisease-(covid-2019)-and-the-virus-that-causes-it

4. Wikimedia. 62-COVID-19 pandemic in Indonesia - Wikipedia [Internet]. 2020. p. 1. Available from: https://en.wikipedia.org/wiki/COVID19_pandemic_in_Indonesia

5. Asri M. Masyarakat Indonesia Dalam Menghadapi Pandemi Virus Corona Covid-19 dan Peraturan Pemerintah. 2020.

6. Kementerian Kesehatan RI. Situasi Terkini Perkembangan Coronavirus (COVID-19) 5 April $2020 »$ Info Infeksi Emerging Kementerian Kesehatan RI [Internet]. Kemenkes RI; 2020. p. 1. Available from: https://covid19.kemkes.go.id/situasi-infeksi-emerging/infocorona-virus/situasi-terkini-perkembangan-coronavirus-covid-19-5-april2020/\#.XonGZFMzZQI

7. Olila D, Kennedy P. 8th Annual Egerton University International Conference: 26 th -28 th March, 2014. 2014;(May).

8. Utomo N. Hubungan Tingkat Pengetahuan Risiko Penyakit Akibat Kerja dengan Kesadaran Pemakaian Masker Pada Pekerja Bagian Operator Jahit CV. Maju Abadi Garment Sukoharjo. Fak Ilmu Kesehat Univ Muhammadiyah Surakarta. 2015;151:10-7.

9. Sulistyaningtyas T. 57-Data Riset dan Teknologi Covid-19 Indonesia [Internet]. Bandung: Institut Teknologi $\quad$ Bandung; 2020. Available from: https://sinta.ristekbrin.go.id/covid/penelitian/detail/80

10. Yanti B, Wahyudi E, Wahiduddin W, Novika RGH, Arina YMD, Martani NS, et al. Community Knowledge, Attitudes, and Behavior Towards Social Distancing Policy As Prevention Transmission of Covid-19 in Indonesia. J Adm Kesehat Indones. 2020;8(2):4.

11. Putri R. Hubungan antara Tingkat Pendidikan dan Tingkat Pengetahuan dengan Perilaku Hidup Sehat Kualitas Lingkungan Rumah. Sereal Untuk. 2018;51(1):51.

12. Clements JM. Knowledge and behaviors toward COVID-19 among us residents during the early days of the pandemic: Cross-sectional online questionnaire. J Med Internet Res. 2020;22(5):1-11.

13. Al-hanawi MK. Knowledge, Attitude and Practice Toward COVID-19 Among the Public in the Kingdom of Saudi Arabia : A Cross-Sectional Study. 2020;8(May):1-10.

14. Pangesti A. Gambaran Tingkat Pengetahuan Dan Aplikasi Kesiapsiagaan Bencana Pada Mahasiswa Fakultas Ilmu Keperawatan Universitas Indonesia Tahun 2012. 2012;93. Available from: http://lib.ui.ac.id/file?file=digital\%2F20313898-S42573Gambaran+tingkat.pdf

15. Olaimat AN, Aolymat I, Shahbaz HM, Holley RA. Knowledge and Information Sources About COVID-19 Among University Students in Jordan: A Cross-Sectional Study. Front Public Heal. 2020;8(May).

16. Syafrida S. Bersama Melawan Virus Covid 19 di Indonesia. SALAM J Sos dan Budaya Syar-i. 2020;7(6).

17. Hiday ZN. Faktor-Faktor yang Berhubungan dengan Praktik Penggunaan Masker Pada Pekerja Bagian Pencelupan Benang PT X Di Kabupaten Pekalongan. J Chem Inf Model [Internet]. 2013;53(1):1689-99. Available from: http://ir.obihiro.ac.jp/dspace/handle/10322/3933\%0Ahttps://doi.org/10.1016/j.jag.2018.0 7.004\%0Ahttp://dx.doi.org/10.1038/s41598-018-25369-w\%0Ahttps://www.bertelsmannstiftung.de/fileadmin/files/BSt/Publikationen/GrauePublikationen/MT_Globalization_Re port_

18. Soendoro A. Kepatuhan Pemakaian APD Pekerja Bagian Weaving SKRIPSI. 2016;

19. Yuliastuti C, Novita NW, Narsih S. Tingkat Pengetahuan TB Paru Memepengaruhi 
Penggunaan Masker Pada Penderita TB Paru. J Ilm Kesehat. 2014;7:122-37.

20. Devi Pramita Sari, Nabila Sholihah 'Atiqoh. Hubungan Antara Pengetahuan Masyarakat Dengan Kepatuhan Penggunaan Masker Sebagai Upaya Pencegahan Penyakit Covid-19 Di Ngronggah. Infokes J Ilm Rekam Medis dan Inform Kesehat. 2020;10(1):52-5. 